\title{
Effect Of Apramycin On Pathological, Hematological And Biochemical Changes In Turkey Infected With Coli-Bacillosis
}

\author{
Tharwat I Ahmed ${ }^{1}$, El Nabarawy E A A $^{2}$ Aly Salah A B S $S^{3}$ and Hassan A A ${ }^{4}$ \\ Animal Health Research Institute (Zagazig ${ }^{1 \& 2}$ ) \\ Kafr El Sheikh ${ }^{3}$ and Damanhur ${ }^{4}$ Branch
}

\begin{abstract}
Eighty turkey poults 20 days old were equally divided into 4 equal groups to evaluate the efficacy of Apramycin against the colibacillosis; group1 was kept as control, group 2 received $25 \mathrm{mg} / \mathrm{kg}$.b.wt. of Apramycin in drinking water for 5 successive days, the group3 3 was infected with $3 \times 10^{9}$ organisms of E.coli (O78)and group 4 was infected with E.coli and treated with Apramycin .Five poults from each group was sacrificed, 1,15 and 20 day from the beginning of the experiment.

Two blood samples were taken and the serum was separated for hematological and biochemical studies. Tissue specimens were collected for drug- residues assessment and for pathological examination. The poults of group3 shows significant decrease in RBCs, Hb ,PCV\% ,total proteins, albumin ,globulins with insignificant increase in $\mathrm{A} / \mathrm{G}$ ratio. and significant elevation in WBCs ,AST ,ALT ,ALP, Uric acid and Creatinine These changes were lowered in group 4.The ,respectively, then disasidues were present in the kidneys ,liver, skin and thigh muscles treatment. The pathological completely rom the examined organ samples after 20 days post changes included degenerative chantions were coincided with the biochemical examination these to coagulative necrosis in changes in hepatocytes, epithelial lining of renal tubules in addition infiltrations were noticed. Finally, it could and renal parenchyma. Congestion and leukocytic Colibacillosis, in turkey poults.
\end{abstract}

\section{INTRODUCTION}

Escherichia coli, usually abbreviated to E.coli, is one of the main species of bacteria normally inhabitants of the lower intestines of warm-blooded animals (birds and mammals) (1). Colibacillosis affects poultry industry causing serious economic losses achieved by high mortality and loss of body weight (2). Colibacillosis was associated with various disease conditions (3). The acute form in poultry leads to septicemia and death (4).

Escherichia coli serotype O78 is highly pathogenic for chickens and can induce mortalities within short time (5).

Escherichia.coli infection in poultry is associated with pericarditis, perihepatitis, nephritis, air-sacculitis, peritonitis, panophthalmitis and omphalitis. There were also degenerative changes in most organs of the affected chickens, represented by vacuolar and hydropic degenerations in addition to necrosis of hepatocytes and renal parenchyma. .Blood vessels of most organs were congested, sometimes hyperplasia of their walls. Colibacillosis causes an elevation of AST, ALT and ALP, in addition to increase in Total proteins, Albumin, Globulins, Uric acid and Creatinine. (6).

Aminoglycoside antibiotics play an important role in treatment E.coli in poultry (7). Apramycin is a broad-spectrum aminoglycoside antibiotic produced by a strain Streptomyces tenebrarius strain (8). It is extracted from the fermentation medium as Apramycin sulphate. A microbiological assay is used to determine its 
activity as equivalents of Apramycin base. Apramycin was used in the treatment of Colibacillosis in poultry. Apramycin leads to a decrease in RBCs count, Hb, PCV. An increase in WBCs count due to E.coli infection, decreased after Apramycin administration to infected chickens $(9,10)$.

The present work was conducted to throw light on the efficacy of Apramycin in controlling E.coli infection in turkey poults and their effects on hemato-biochemical parameters and pathological changes in some internal organs associated with this infection and treatment, as well as detection of Apramycin residues in internal organs.

\section{MATERIAL AND METHODS} Drugs

Apramycin : Apramycin sulfate soluble powder obtained from Unipharma Company for medical industry. Its traditional name is Apracin, each $150 \mathrm{gm}$ of this powder contains $78 \mathrm{gm}$ Apramycin sulphate. Apramycin is an aminoglycoside antibiotic produced by Streptomyces tenebrarius.

Experimental Turkey Poults

A total of 80 healthy one day old turkey poults were obtained from local commercial hatchery. Turkey poults were floor reared under hygienic condition, fed on balanced ration free from any medications and given water adlibitum. All turkey poults were subjected to bacteriological examination and proved to be free from infection before E.coli inoculation . Microorganisms

E.coli strain (O.78) used in this study was isolated from a field case from broiler chickens farms infected with colisepticaemia in Sharkia Governorate. Identified and serotyped as O78 $(11,12)$.
E. coli inoculum: Broth culture was standardized to give bacterial suspension containing $3 \times 10^{9}$ viable organism $/ \mathrm{ml}$ of E.coli O78 using MacFerland tube. Each bird was given $0.3 \mathrm{ml}$ via nasal route (13).

\section{Experimental Design}

At $20^{\text {th }}$ day of age turkey poults, were divided into four equal groups (20 each). $1^{\text {st }}$ group turkey poults were left non infected non treated (-ve control), $2^{\text {nd }}$ group healhy turkey poults treated with Apramycin $(25 \mathrm{mg} / \mathrm{kg} \mathrm{B}$.wt in drinking water for 5 successive days), $3^{\text {rd }}$ and $4^{\text {th }}$ groups were expermintally infected with E.coli at the $20^{\text {th }}$ day of age, $3^{\text {rd }}$ group infected, non-treated turkey poults (+ve control), $4^{\text {th }}$ group infected turkey poults and treated with Apramycin at the same dose and period.Treatment started 24 hrs post infection. All diseased turkey Poults were left under observations during the experimental period to record the clinical symptoms and mortality rate.

\section{Sampling}

\section{Blood Samples}

Five birds from each group were slaughtered at $1^{\text {st }}, 15^{\text {th }}$ and $20^{\text {th }}$ day post treatment for collection of 2 blood samples.The $1^{\text {st }}$ sample was taken in a tube containing EDTA and used for hematological studies, the $2^{\text {nd }}$ sample was taken to obtain clear serum for estimation of AST, ALT and ALP, T. proteins, serum albumin, globulins mathematically, uric acid and creatinine according to (14).

Media Used: MacConkey's agar, nutrient agar, MacConkey's broth and Nutrient broth

Swabs for re-isolation of E.coli (O78)

Sterilized swabs from trachea, lung, heart, liver and air sacs were taken from sacrificed turkey poults for bacteriological examination for re-isolation of inoculated E.coli. Swabs were incubated in nutrient broth at $37^{\circ} \mathrm{C}$ for 24hrs, then subcultured into MacConkey's agar then incubated at $37^{\circ} \mathrm{C}$ for $24 \mathrm{hrs}$ (15). Reisolated bacteria were identified biochemically and serology (16). 
Tissue Samples for drug residues

Samples were taken from slaughtering turkeys post treatment from thigh muscles, liver, kidney and skin for determination of Apramycin residues (17).

Preparation of medium and test plates

Per $100 \mathrm{ml}$ of Apramycin medium at $48^{\circ} \mathrm{C}$, $1 \mathrm{ml}$ of micrococcus spore suspension $\left(10^{7}\right.$ spore $\left./ \mathrm{ml}\right)$ was added to obtain a density of $10^{4}$ spore $/ \mathrm{ml}$. The medium was shaked well and $13 \mathrm{ml}^{3}$ of the prepared medium was poured into a number of petri dishes $(1 \mathrm{~cm}$ depth).The plates were left at room temperature tell complete solidification, then 6 pores were made on each plate using sterile borer with outside diameter 8 $\mathrm{mm}$.

Procedure

Two plates spilled with different concentrations of Apramycin were used, and then plates were incubated at $30^{\circ} \mathrm{C}$ for $24 \mathrm{hrs}$. The width of inhibition zones were recorded then marking a curve between concentration of Apramycin and width of inhibition zone. The same procedure was done for turkey Poults tissues and the concentration of Apramycin was determined by comparing with those obtained by calibration curve.

Specimens for histopathological studies

Specimens from the liver and kidneys were taken from sacrificed birds then fixed in $10 \%$ neutral formalin solution and embedded in paraffin. Five microns thick sections were prepared and stained by $H \& E$ then examined microscopically (18).

5) Statistical analysis: The obtained data was analyzed (19).

RESULTS
The obtained results were tabulated in tables 1,2,3, 4 and 5 and Figures 1 to 6.

Table1. Effect of Apramycin on the mortality rate, pathological lesions and reisolation in healthy and E.coli infected turkey poults

\begin{tabular}{|c|c|c|c|c|c|c|c|c|c|}
\hline \multirow{2}{*}{ Group } & \multirow{3}{*}{$\begin{array}{c}\text { Total } \\
\text { No }\end{array}$} & \multicolumn{2}{|c|}{ Mortality } & \multicolumn{6}{|c|}{ Lesion scores \% } \\
\hline & & \multirow[t]{2}{*}{ No } & \multirow{2}{*}{$\%$} & \multicolumn{2}{|c|}{ Air sacculitis } & \multicolumn{2}{|c|}{ Pericarditis } & \multicolumn{2}{|c|}{ Perihepatitis } \\
\hline Non-inf., non treated & & & & No & $\%$ & No & $\%$ & No & $\%$ \\
\hline Non Inf. Treated & $\begin{array}{l}20 \\
20\end{array}$ & 00 & 00 & 00 & 00 & 00 & 00 & 00 & 00 \\
\hline Inf. Non treated & 20 & 00 & 00 & 00 & 00 & 00 & 00 & 00 & 00 \\
\hline Inf. Treated & $\begin{array}{l}20 \\
20\end{array}$ & 5 & 25 & 15 & 75 & 17 & 85 & 13 & 65 \\
\hline & & 1 & 5 & 4 & 20 & 2 & 10 & 3 & 15 \\
\hline
\end{tabular}

Table 2. Re-isolation of E.coli from infected non treated and infected treated turkey poults

\begin{tabular}{|c|c|c|c|c|c|c|c|c|c|c|c|}
\hline \multirow{2}{*}{ Parameters } & \multirow{3}{*}{$\begin{array}{c}\text { No. of } \\
\text { Examined } \\
\text { poults }\end{array}$} & \multicolumn{10}{|c|}{ Trachea-isolation of E. coli for internal organs } \\
\hline & & \multicolumn{2}{|c|}{ Trachea } & \multicolumn{2}{|c|}{ lung } & \multicolumn{2}{|c|}{ Heart } & \multicolumn{2}{|c|}{ Liver } & \multicolumn{2}{|c|}{ Air sacs } \\
\hline Non-inf., non & & No & $\%$ & No & $\%$ & No & $\%$ & No & $\%$ & No & $\%$ \\
\hline $\begin{array}{l}\text { treated } \\
\text { Non }\end{array}$ & 20 & 0 & 00 & 00 & 00 & 00 & 00 & 00 & 00 & 00 & 00 \\
\hline Inf., Treated & 20 & 0 & 00 & 00 & 00 & 00 & 00 & 00 & 00 & 00 & 00 \\
\hline treated & 20 & 20 & 100 & 16 & 80 & 12 & 60 & 09 & 45 & 15 & 75 \\
\hline Inf., Treated & 20 & 2 & 10 & 1 & 5 & 1 & 5 & 1 & 5 & 3 & 06 \\
\hline
\end{tabular}


Tharwat et al.,

Table 3. Effect of Apramycin on Blood picture of healthy and infected turkey poults with E.coli

\begin{tabular}{|c|c|c|c|c|c|c|}
\hline \multirow[t]{3}{*}{ Gro } & \multirow{3}{*}{$\begin{array}{l}\text { Healthy } \\
\text { turkey } \\
(\mathrm{n}=5)\end{array}$} & \multirow{3}{*}{$\begin{array}{c}\text { Healthy } \\
\text { treated } \\
\text { turkey } \\
(\mathrm{n}=5)\end{array}$} & \multicolumn{4}{|c|}{ Diseased turkey $(\mathrm{n}=5)$} \\
\hline & & & \multirow{2}{*}{$\begin{array}{l}\text { Non } \\
\text { treated }\end{array}$} & \multicolumn{3}{|c|}{ Post treatment (days) } \\
\hline & & & & 1 & 15 & 20 \\
\hline RBCs $(106 / \mu \mathrm{l})$ & $5.73 \pm 0.37$ & $4.06 \pm 0.48^{*}$ & $3.82 \pm 0.32^{* * *}$ & $4.12 \pm 0.42 *$ & $4.32 \pm 0.29^{*}$ & $5.54 \pm 0.49$ \\
\hline $\mathrm{Hb}(\mathrm{gm} / \mathrm{dl})$ & $10.70 \pm 0.58$ & $8.33 \pm 0.63^{*}$ & $7.94 \pm 0.77^{*}$ & $8.31 \pm 0.62 *$ & $8.93 \pm 0.50^{*}$ & $10.55 \pm 0.72$ \\
\hline PCV\% & $28.42 \pm 0.94$ & $25.14 \pm 0.92 *$ & $24.55 \pm 0.99 *$ & $26.03 \pm 0.24 *$ & $28.08 \pm 0.51$ & $28.41 \pm 0.60$ \\
\hline WBCs $(106 / \mu \mathrm{l})$ & $15.38 \pm 0.91$ & $18.96 \pm 0.97^{*}$ & $19.21 \pm 0.99 *$ & $1796 \pm 0.62 *$ & $16.64 \pm 0.50$ & $1614 \pm 0.58$ \\
\hline
\end{tabular}
Table 4. Effect of Apramycin on liver and kidney functions in healthy and infected turkey
poults with E.coli $(n=5)$

\begin{tabular}{|c|c|c|c|c|c|c|c|c|c|c|c|}
\hline \multirow{3}{*}{\multicolumn{3}{|c|}{ Parameters }} & \multicolumn{7}{|c|}{$\begin{array}{ll} & \text { Liver Functions } \\
\text { Liver enzymes }(\mathrm{u} / \mathrm{ml})\end{array}$} & \multicolumn{2}{|c|}{ Kidney Functions } \\
\hline & & & \multicolumn{3}{|c|}{ Liver enzymes(u/ml) } & \multicolumn{4}{|c|}{ Protein profile $(\mathrm{gm} / \mathrm{dl})$} & \multirow{2}{*}{$\begin{array}{l}\text { Uric } \\
\text { acid } \\
(\mathrm{mg} / \mathrm{dl})\end{array}$} & \multirow{2}{*}{$\begin{array}{c}\text { Creatinine } \\
(\mathrm{mg} / \mathrm{dl})\end{array}$} \\
\hline & & & AST & $\overline{\mathrm{ALT}}$ & ALP & $\begin{array}{c}\mathrm{T} . \\
\text { proteins }\end{array}$ & Albumin & Globulin & $\begin{array}{l}\mathrm{A} / \mathrm{G} \\
\text { ratio } \\
\end{array}$ & & \\
\hline \multirow{3}{*}{ 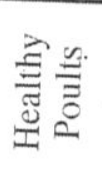 } & \multirow{2}{*}{\multicolumn{2}{|c|}{$\begin{array}{c}\text { Non } \\
\text { treated } \\
\text { Treated }\end{array}$}} & $\begin{array}{r}77.12 \\
\pm 1.05\end{array}$ & $\begin{array}{l}30.21 \\
\pm 0.58\end{array}$ & $\begin{array}{c}110.04 \\
\pm 0.93\end{array}$ & $\begin{array}{c}5.26 \\
\pm 0.29\end{array}$ & $\begin{array}{c}3.01 \\
\pm 0.12\end{array}$ & $\begin{array}{c}2.25 \\
\pm 0.15\end{array}$ & $\begin{array}{c}1.34 \\
\pm 0.12\end{array}$ & $\begin{array}{c}3.90 \\
\pm 0.22\end{array}$ & $\begin{array}{c}1.52 \\
\pm 0.21\end{array}$ \\
\hline & & & 80.09 & 33.04 & 115.13 & 3.84 & 2.41 & 1.43 & 1.69 & 4.87 & \\
\hline & \multirow{2}{*}{\multicolumn{2}{|c|}{$\begin{array}{l}\text { Non } \\
\text { treated }\end{array}$}} & $\pm 0.90^{*}$ & $\pm 0.72 * *$ & $\pm 1.64 *$ & $\pm 0.40 *$ & $\pm 0.19 *$ & $\pm 0.25 *$ & & \pm 0.1 & \\
\hline \multirow{6}{*}{ 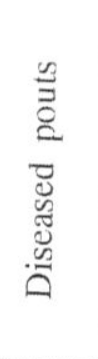 } & & & $\begin{array}{c}81.15 \\
\pm 1.13^{*}\end{array}$ & $\begin{array}{c}33.11 \\
\pm 0.83^{*}\end{array}$ & $\begin{array}{l}115.06 \\
\pm 1.92 \%\end{array}$ & $\begin{array}{c}4.16 \\
\pm 0.28^{*}\end{array}$ & $\begin{array}{c}2.30 \\
\pm 0.21 *\end{array}$ & $\begin{array}{c}1.86 \\
\pm 0.10^{*}\end{array}$ & $\begin{aligned} & 1.24 \\
\pm & 0.18\end{aligned}$ & $\begin{array}{c}4.97 \\
\pm 0.19^{* * *}\end{array}$ & \\
\hline & & 1 & 80.10 & 3253 & 113.41 & 4.58 & 2.68 & 1. & 1.41 & 4.73 & \\
\hline & 空 & & $\pm 0.70 *$ & $\pm 0.52 *$ & $\pm 1.30 *$ & $\pm 0.11^{*}$ & $\pm 0.09 *$ & \pm 0 & \pm 0.15 & $\pm 0.19 *$ & \\
\hline & ᄅِ & 15 & $\begin{array}{r}79.04 \\
\pm 0.45\end{array}$ & $\begin{array}{r}32.10 \\
+\quad 0.30 *\end{array}$ & 111.39 & 4.79 & 2.81 & 1.9 & 1.42 & 4.3 & \\
\hline & $\pi$ & 20 & 78.88 & 30.90 & $\begin{array}{l} \pm 1.55 \\
11050\end{array}$ & \pm 0.17 & \pm 0.10 & \pm 0 & & & \\
\hline & & & \pm 0.85 & \pm 0.28 & $\begin{array}{l}110.59 \\
\pm 1.28\end{array}$ & $\begin{array}{c}5.11 \\
\pm 0.21\end{array}$ & $\begin{array}{c}2.96 \\
\pm 0.14\end{array}$ & $\begin{array}{c}2.15 \\
\pm 0.16\end{array}$ & $\begin{array}{c}1.38 \\
\pm 0.23\end{array}$ & $\begin{array}{c}3.98 \\
\pm 0.10\end{array}$ & \\
\hline
\end{tabular}

Table 5. Apramycin residues $(\mu \mathrm{g} / \mathrm{g})$ in fresh turkey poults tissues and organs

\begin{tabular}{ccccccc}
\multirow{2}{*}{ Organ } & \multicolumn{4}{c}{ Days post slaughter (days) } \\
\cline { 2 - 7 } & \multicolumn{3}{c}{ Healthy poults treated with } & \multicolumn{3}{c}{ Diseased Poults treated with } \\
Apramycin
\end{tabular}


Pathological finding

Groups 1,2: Control and received Apramycin. Neither Gross nor microscopical abnormalities were seen.

Group 3,4: Infected (non-treated) and infected (treated).

\section{Macroscopically}

The liver and kidneys of Group (3) showed severe congestion, firm and focal whitish necrotic foci, moreover, thickening of the hepatic and kidney capsules were noticed, in few cases, focal hemorrhagic spots were seen in the renal cortex. The liver and kidneys in most cases of group 4 were dark red to brownish in color and enlarged in size.

\section{Microscopically}

The liver of group 3: showed congestion of the hepatic blood vessels, the liver revealed thrombosis and thickening of the wall of the portal vein, besides leukocytic aggregations in hepatic parenchyma and hemorrhage. (Fig.1).Degenerative changes coagulative necrosis of hepatic parenchyma which represented by pyknosis karyorrhexis and karyolysis of the nuclei of hepatocytes. (Fig.2).

The kidneys of group 3: showed hypercellularity of the glomeruli in addition to degenerative changes which represented by vacuolar and hydropic degenerations and perivascular edema (Fig.3). In some cases, focal coagulative necrosis of the epithelial lining renal tubules, hyperplasia and thickening of the renal capsule was also observed (Fig.4).Congestion of the renal blood vessels and leukocytic aggregations in renal parenchyma was also observed. Most infected cases with E.coli, the lining renal tubules showed cloudy swelling and individual cell necrosis which represented by pyknosis and karyorrhexis of their nuclei (Fig.5).

The lesions of group4 were alleviated than those described in group3. Mild degenerative changes (vacuolar and hydropic types),slight congestion and few round cells infiltrations were visualized.(Fig.6). 


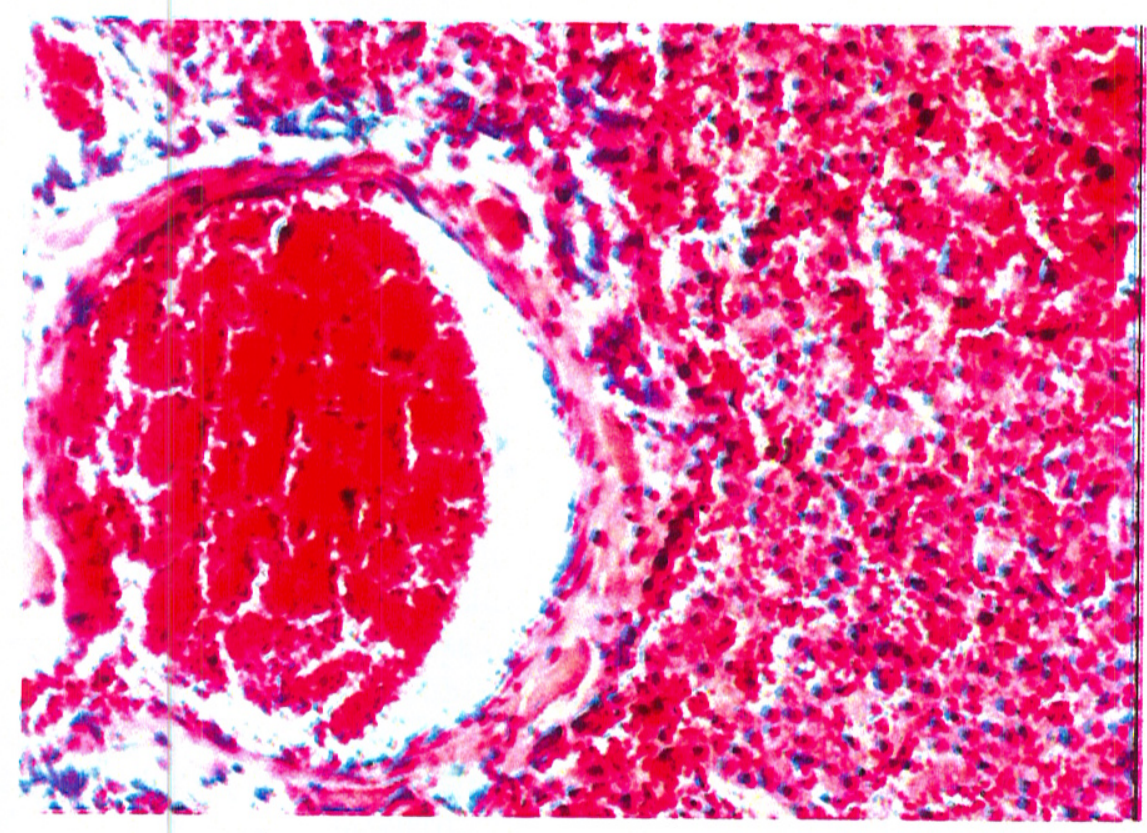

Fig.1. Electromicrograph of the liver of Group 3 showing congestion of the hepatic blood vessels and thrombosis and thickening of the wall of the portal vein in addition to leukocytic aggregations in hepatic parenchyma $H \& E \times 200$.

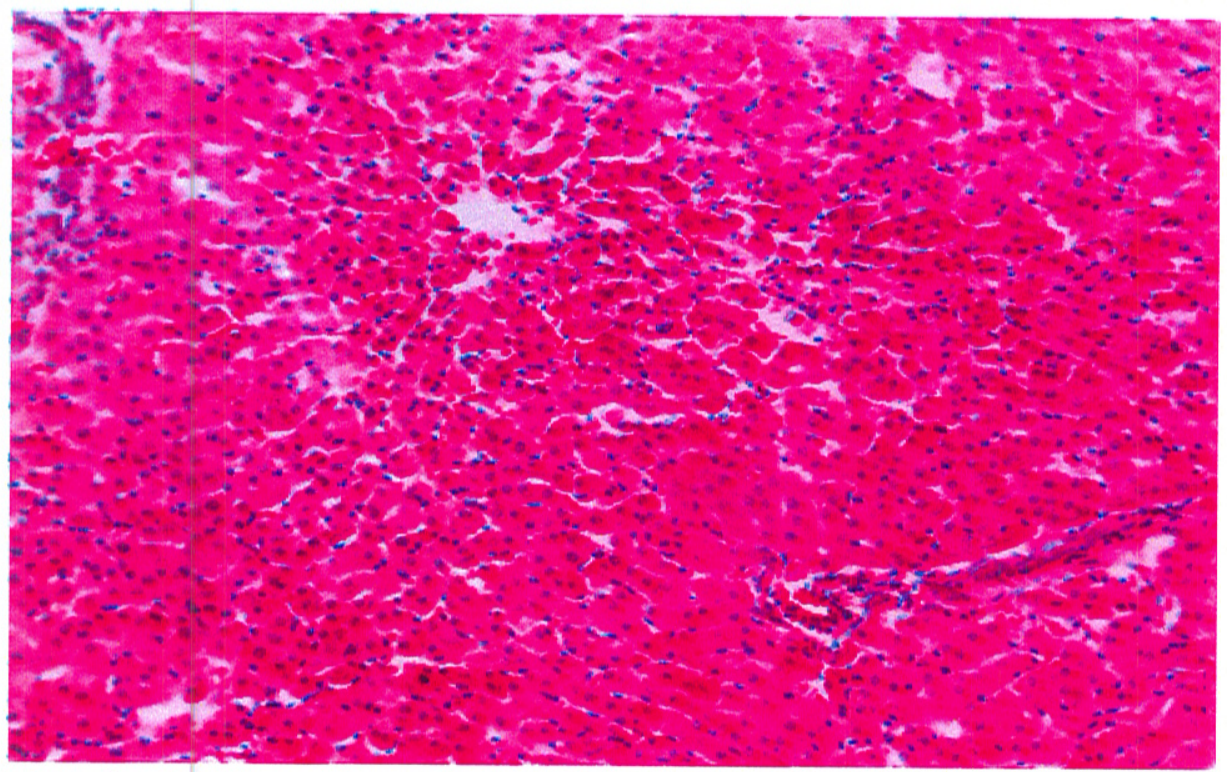

Fig.2. Electromicrograph of the liver of Group 3 showing focal coagulative necrosis of hepatic parenchyma $\mathrm{H} \& \mathrm{E} \times \mathbf{1 0 0}$. 


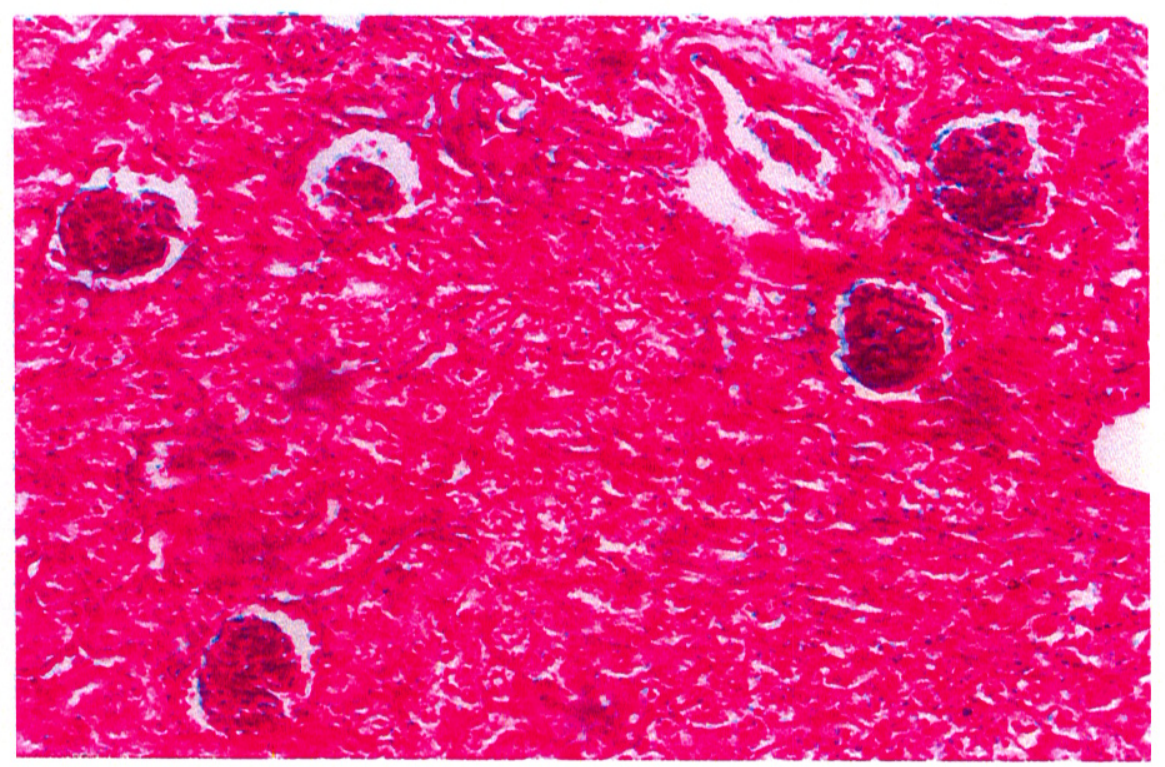

Fig. 3. Electromicrograph of the kidney of Group 3 showing vacuolar and hydropic degenerations of renal tubules in addition to hypercellularity of glomeruli and perivascular edema $\mathrm{H} \& \mathrm{E} \times \mathbf{2 0 0}$

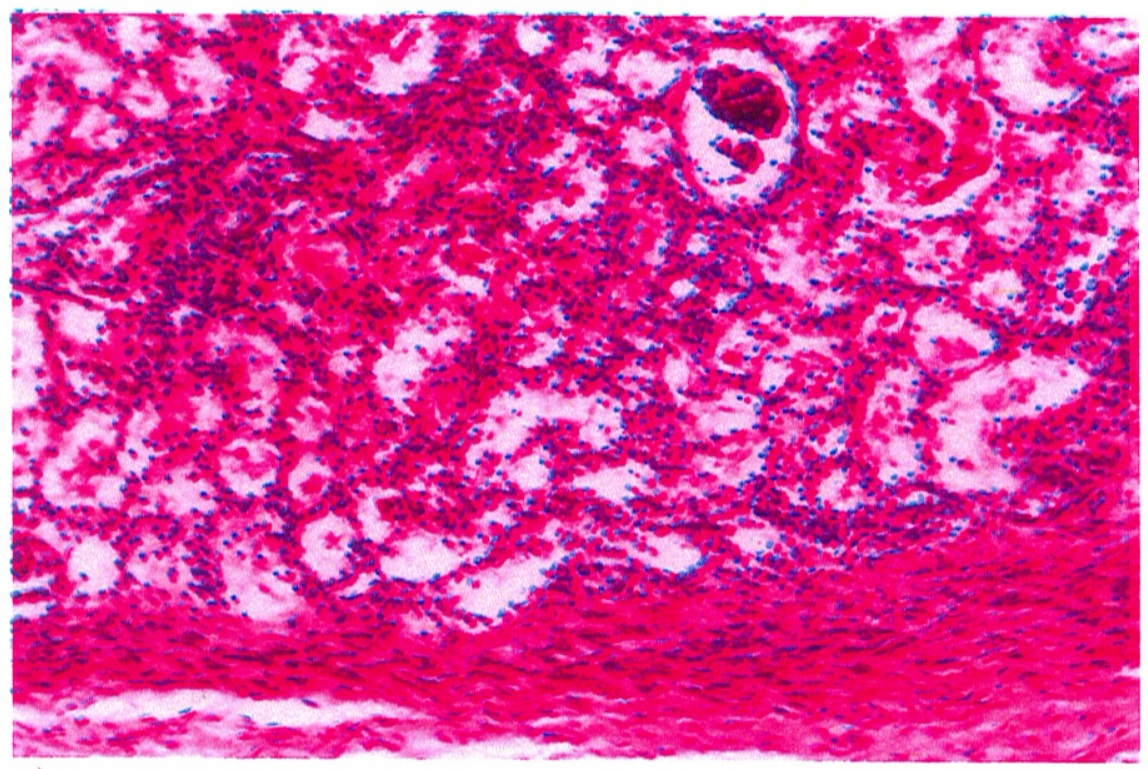

Fig. 4. Electromicrograph of the kidney from infected turkey poults treated with Apramycin showing Focal coagulative necrosis of the epithelial lining renal tubules with hyperplasia of the renal capsule $\mathrm{H} \& \mathrm{E} \times \mathbf{2 0 0}$ 


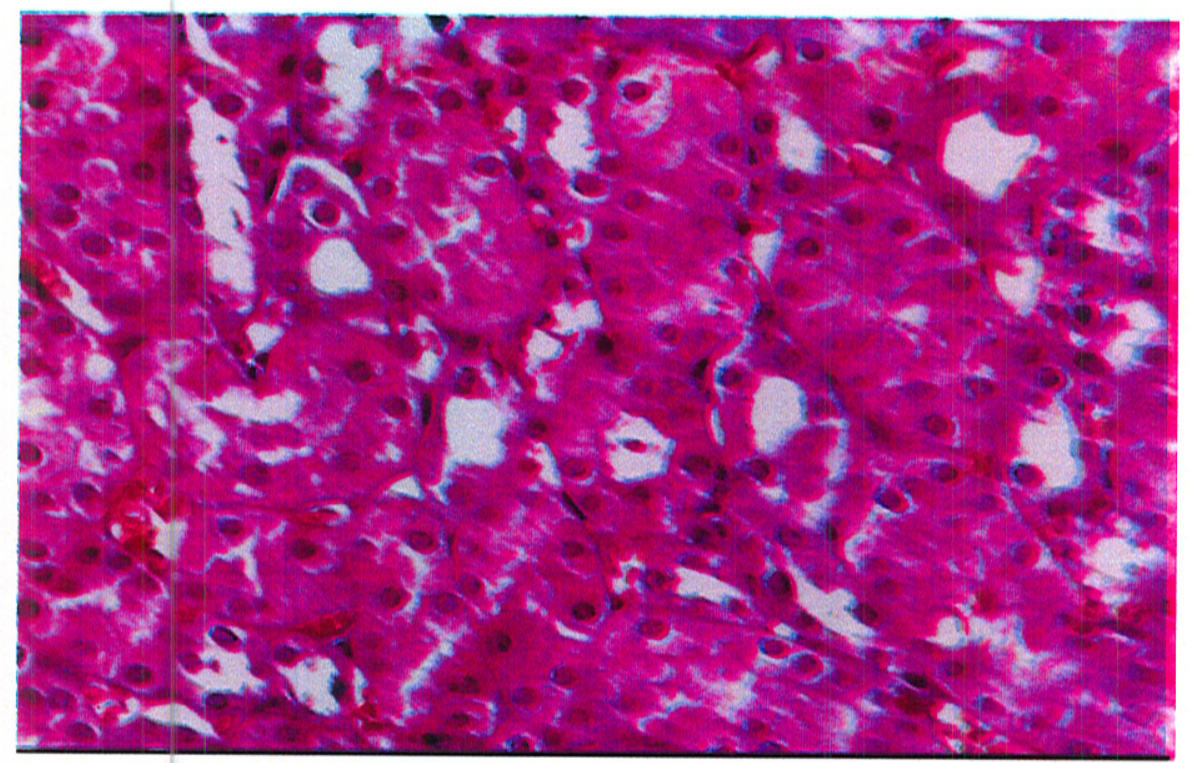

Fig. 5. Electromicrograph of the kidney: $y$ of Group (3) showing cloudy swelling and individual cell necrosis of the epithelial lining of renal tubules which represented by karyorrehxis and karyolysis of their nuclei H\&E $\times 300$

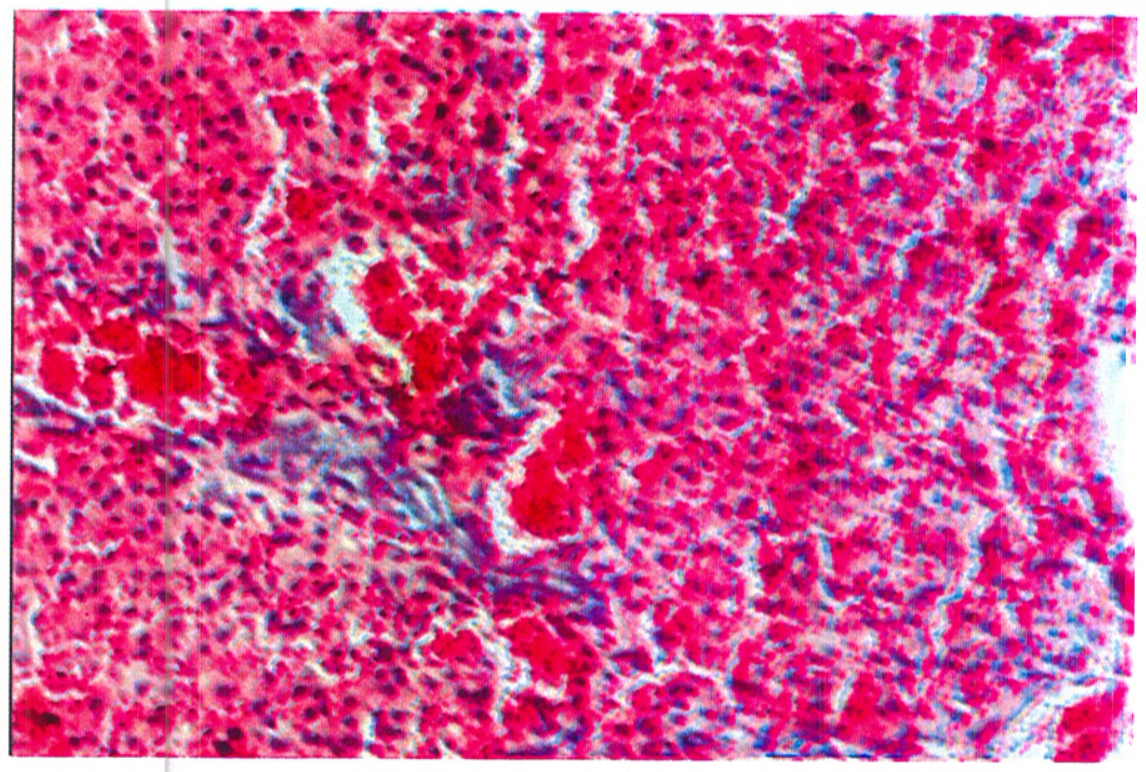

Fig. 6. Electromicrograph of the liver of Group 4 showing congestion of the hepatic blood vessels and sinusoids $\mathrm{H} \& \mathrm{E} \times \mathbf{2 0 0}$ 


\section{DISCUSSION}

Turkey poult experimentally infected with E coli displayed clinical signs as loss of appetite, weakness, depression, sneezing, cough, depression, watery diarrhea and $25 \%$ mortality The same signs were recorded in broiler chickens $(12,20)$. Mortality rate in E.coli infected broiler ranged from $10-40 \%(21,22)$ who found that mortality rate in broilers infected with $\mathrm{E}$ coli was $40 \%$.

Effects of Apramycin on blood picture in healthy and infected turkey poults with E.coli showed significant reduction in RBCs, Hb, PCV and leukocytosis. (Table,3).Same changes were recordedwhich showed that apramycin induced significant decrease in RBCs, $\mathrm{Hb}, \mathrm{PCV}$ in broilers. (25). Aminosidine another aminoglycoside was found to induce decrease in RBCs, $\mathrm{Hb}$ and PCV and leukocytosis (24). Our results proved previous observations which recorded that broilers infected with E.coli showed significant decrease in RBCs, $\mathrm{Hb}$ and PCV.(25). Rduction in erythrogram may be due to lipopolysaccharide toxin secrted by E.coli which inhibits bone marrow cells and nephrotoxicity decrease erythropoietin blood level which followed by decrease RBCs formation (26). Also, it has been shown that bacterial endotoxins cause intra-vascular destruction of erythrocytic cells leading to haemolysis with break down of $\mathrm{Hb}(27)$. Leukocytosis in E. coli infected birds may be due to inflammatory response in the gastrointestinal tract due to bacterial infection (28).

Analysis of protein profile of the healthy turkey poults treated with Apramycin and those infected with $\mathrm{E}$. coli showed significant decrease in total proteins, albumin and globulins (Table 4). Similar findings were previously cited by (29) which showed that apramycin evoked a significant decrease in proteins, albumin and globulins in rabbits. Decrease in serum protein picture in turkey poults treated with Apramycin might be due to damage in hepatic cells (30). Broiler chickens infected with E.coli showed significant decrease in serum total proteins, albumin and globulins $(2,31,32)$. Decrease in albumin in birds infected with E. coli could be due to liver damage in which liver is the sole site of albumin synthesis (30).

In the present study, healthy turkey poults treated with Apramycin and infected with $\mathrm{E}$ coli showed significant increase in serum AST, ALT and ALP, uric acid and creatinine (Table 4) Our results were supported by previous study (23) which indicated that healthy rabbits treated with Apramycin showed significant increase in AST, ALT, ALP, uric acid and creatinine. Increase in uric acid and creatinine post administration of Apramycin may be due to accumulation and retention of Apramycin in proximal tubular cells inducing kidney damage (33). Our results are in accordance with the results obtained by previous authors $(34,35)$, where they found that E.coli infection in broiler induce a significant increase in AST, ALT, uric acid and creatinine, in broilers infected with E.coli which may be due to liver damage induced by the organism and its toxins which lead to escape of these enzymes into serum (36).

Our findings revealed that, Apramycin residues in the examined samples of turkey poults liver, muscle, kidney and skin were very high at 1st day of clearance period, , very low at 15 th days post treatment and completely disappeared from all examined organ at 20th day post treatment. The highest levels of Apramycin residues were recorded in the kidney followed by liver then skin and muscle(Table5).The obtained results nearly coincide with those previously reported (37) which showed that, the average total residues of Apramycin at 1 st day of withdrawal were 3.23 , $0.42,0.20$ and $0.07 \mathrm{mg} / \mathrm{kgm}$ in kidney, liver, skin and muscle, respectively. After 14 days, average of total residue had declined to 0.47 , $0.08,0.03$ and $0.02 \mathrm{mg} / \mathrm{kg}$ in the same respective tissues. The highest Apramycin residue was present in the kidneys followed by liver (8).

Gross pathological lesions present in our study in group3 (infected group) were perihepatitis, pericarditis, air sacculitis misshaped and congestion these lesion scores percentages were decreased in group4 (infected 
and treated). Poultry infected with E.coli. manifested the previously mentioned lesions (25). Healthy turkey poults treated with Apramycin showed pathological lesions as congestion of hepatic blood vessels with vacuolar degeneration of hepatocytes, kidney showed focal coagulative necrosis of renal tubular epithelium. The histopathological findings could be due to septicemic effect of $E$. coli upon the blood vessels, serous membranes and the parenchymatous organs (38). Same lesions were recorded previously (39) in Guinea pigs given Apramycin. Liver showed congestion of hepatic sinusoids, vacuolation in some hepatic lobules and hydropic degeneration, coagulative necrosis and lymphocytic infiltrations. Kidney showed cystic dilatation, hydropic degeneration of some renal tubules and desquamation of some epithelial lining of the renal tubules in turkey poults infected with $\mathrm{E}$ coli. Our results were nearly similar to that recorded by several authors $(40-42)$.

\section{CONCLUSION}

From this study we concluded that, Apramycin is effective for treatment and improvement of the liver and kidney functions after infection by Escherichia coli (E.coli 078) in turkey poults. As E. coli infection has adverse effect on liver and kidney functions in addition to degenerative changes and necrosis of hepatocytes and epithelial lining renal tubules. Apramycin residues was detected in kidney, liver and skin respectively and removed completely from body organs after 20 days of Apramycin treatment. It is advised to use Apramycin for E.coli treatment of turkey poults.

\section{REFERENCES}

1.Rosario C, Lopaz A, Tellez I, Navarro $O$ and Eslava $C$ (2004): Serotyping and virulence genes detection in Escherichia coli isolated from fertile and infertile eggs dead-in-shell embryos and chickens with yolk sac infection. Avian Dis, 48(4):81-89.

2. El-Nemr and Amira $E$ (2011): Efficacy of florfenicol on $\mathrm{E}$ coli infection in chicken. Thesis presented to Fac. of Vet. med.Cairo. Uni. Ph.D.Sc.

3.Otaki Y (1995) :Poultry disease control in Japan. Asian Livestock. 20: 65-67.

4.Calnek B, Barnes H, Beard C, McDougald $L$ and Saif $Y$ (1997): Diseases of Poultry. 10th ed. Iowa State University Press, Ames IA USA: 1997

\section{Sekizaki TL Nonomura and Y Imada} (1998):Loss of virulence associated with olasmid curing of chickens pathogenic E.coli. J.Japanese Vet. Sci. 51:659-661.

\section{La Ragione $R$ and Woodward M (2002):} Virulence factors of $E$. coli serotypes associated with avian colisepticemia. Res. Vet. Sci. 73:27-35.

\section{Villemin $P$, Brugere $H$ and Brugere $J$} (1984): Letraitement des infections respiratories des volailles. Recueil de Med. Vet. 160:117-1128

8. Afifi $R$ (1997): Kinetic disposition systemic bio-availability and tissue distribution of apramycin in broiler chickens. Res. in Vet. Sci 62:49-52

9.El sayed Ahlam A (1990): Antibacterial efficacy of apramycin in chickens. M.V. Sc. Thesis Zagazig Uni.

10. Abd El-Aziz M (2006): Handbook of Veterinary Pharmacology 5th Ed.

11. Quinn P, Carte M, Markeryo B and Carter $G$ (1994): Clinical Veterinary. Microbiology Year book-wolf publishingEurope Limited.

12.Lutful $S$ and Kabir M (2010): Avian Colibacillosis: Epidemiology Pathogenesis Diagnosis Control and Public Health. Int. J. Envi. Res. Public Health. 7(1): 89-114.

13. Nakamura $K$ Cook J, Fraxier $J$ and Narita $M$ (1992):E. coli multiplication and lesions in the respiratory tract of 
chickens inoculated with infectious bronchitis virus and/or E.coli. Avian dis. 36:881-890.

14Jain $\quad N(2000)$ : Schalm's Vet. Haematology 8th Ed.Lea \& Febiger Philadelphia USA.

15. Woldehiwet $Z$, Mamache $B$ and Rowan $T$ (1994): The effects of age enviromental temperture and relative humidity on the bacterial flora of the upper respiratory tract in calves. Br. Vet. J. (146) 211-218.

16. Holt J, Krieg N, Smeadb P, Staley J and Williams $S$ (1994): Bergey's Manual of Determinative Bacteriology.9th.Ed. Williams and Wilkins Co.23-26.

17. Dvorak M, Janeckova I and Strakova $J$ (1987): Tylosin concentrations in the blood and lungs of poultry after administradon in drinking water. Biologizace a chcmizace zivocishe vyroby vet. 23 (4):343.

18.Bancroft $J$, Steven $A$ and Turner $D$ (1990): Theory and practice of histological techniques 3rd Ed.Churchill Livingston Edinburgh London and New York.

19. Petri $A$ and Watson A (1999): Statistical for Vet. Animal Sci. Ltd. United Kingdom.

20.Omer M, Abusalab M, Gumaa S Ahmed A (2010): Outbreak of Colibacillosis among Broiler and Layer Flocks in Intensive and Semi intensive Poultry Farms in Kassala State Eastern Sudan. Asian Journal of Poultry Science 4: 173-181.

21.Youssef $Y$ and Azzam $A$ (1985): Studies on colisepticaemia in chickens in Dakahlia Governorate. Vet. Med. J. 33 (1): 155-161.

22.Hassan Seham M, Sawsan El-Sheikh, AbdelAlim $F$, Taha $M$ and Dalia I (2005) :Effect of the probiotic(Nutrilac)in chicken.Zag.Vet.J.33(2)79-92

23. El-Sadek $S$ (1989): Effect of apramycin on serum constituents with special references to blood picture in rabbits. $\mathrm{Ph}$ Thesis Fac. of Vet. med. Beni Suef Univ.

24.Malhat Seham M (2006): Some Pharmacological Studies on Aminosidine in Chickens. 8th Sci. Vet. Med. Zag. 38-46.

25.Mohamed A K (2004): Interaction between danofloxacin and isoflupredone acetate in chickens. Thesis presented to Fac. of Vet.Med.Zag. Uni. Ph.D. Thesis

26.Tserenpuntag $B$, Chang $H$ and Morse $D$ (2005): Hemolytic uremic syndrome risk and E. coli O157: H7. Emerg Infect Dis , 11(12): 1955-7.

27.Karaivanov $L$ (1984) : Biochemical tests for identifying Pasteurella multocida.Vet. Med. Nauki 21 (9): 38- 44.

28. Doxey $D$ (1983): Clinical pathology and diagnostic procedure 2nd Ed.Baillier London.

29.Ahmed $\quad R$ (1990): Adverse effects of apramycin and cephoperazone in rabbits. $\mathrm{Ph}$ D Thesis Fac. of Vet. med. Moshtohar Benha Univ (Egypt).

30. Kaneko J (1989): Biochemistry of domestic animal Acad. Pres Inc New York.

31.EL-Kadeem AM (2005): Pharmacological studies of gentamicin and ciprofloxacin in colibacillosis in chickens. M.V.Sc. Thesis Fac. Vet. med. Zagazig Uni

32.Shawky Nesreen A (2006): Antibacterial efficacy of Cefoperazone and its combination with sulbactam in chickens. Thesis presented to Fac. of Vet.Med.Zag. Uni. Ph.D.Thesis"pharmacology"

33.Mary J, Richard A, Pamela $C$ and Michael C (2000): Lippincott illustrated reviews: pharmacology". Philadelphia. New York. Press. 314-317.

34.Ibrahim A, El attar A and El-Shahidy $M$ (1998): Studies on E.coli isolates from respiratory affected broilers and protection evaluation of different prepared bacterins. Assiut Vet. med. J. , 37(74): 152-162.

35. EL-Nemr Amira E (2007): Efficacy of spiramycin on colibacillosis in chickens. 
Thesis presented to Fac. of Vet.Med.Cairo. Uni. M.V.Sc.

36.Halliwell W (1981): Serum chemistry profiles in health and disease of birds of prey. In recent advances in the study of Rapter disease edited by cooper J.E and Greenwood A.G. Choin. Publication Ltd. West Yorkshire England.

37. Zornes $L$ Herberg $R$ and Thomson $T$ (1985): 14C Apramycin tissue depletion study in chickens. Lilly Research Laboratories report on experiment $\mathrm{ABC}$ 0294.

38.Filali E, Bell J, El-Houadfi $M$, Huggins $M$ and cook $J$ (1988): Comparative Immunology Microbiology and Infectious Diseases 11(2) 121-124.
39.El-Deeb $E$ (1986): Postmortem and histopathological findings in Guinea pigs intraperitoneally given Apramycin. Ph Thesis Fac. of Vet. Med. Zagazig Univ.

40.Aly A (1989): Study on poultry E.coli infection in Kaluobia Province M.V. Sc.Thesis Microbiology Fac.Vet Med. Cairo Univ.

41.Eisa M (1998): Clinicopathologic studies on some antidiarrheal drugs in rabbits. M.V Sc Thesis. Faculty Vet .med. Zag. Uni. (Clinical Pathology)

42 Khalid A M (1990): Studies on natural and experimental Escherichia coli infection in chickens. J. Egypt. Vet. Med. Ass. 50(3):379-389.

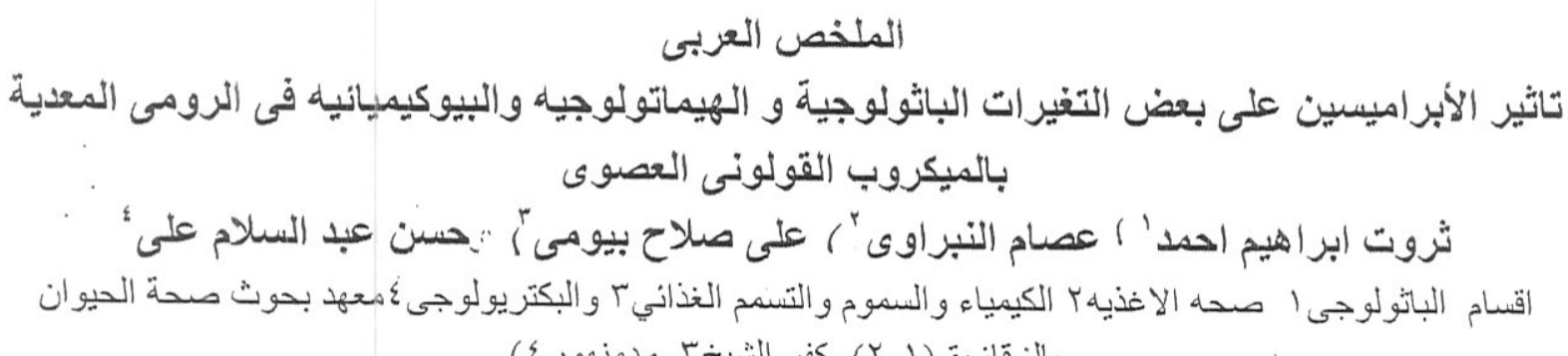

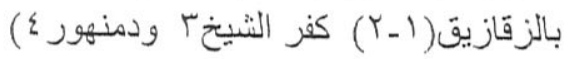

استهدفت هذه الدر اسة معرفة كفاعة الابر اميسين فى علاج العدوى الاصطناعيه بالميكروب العصوى( 078 )

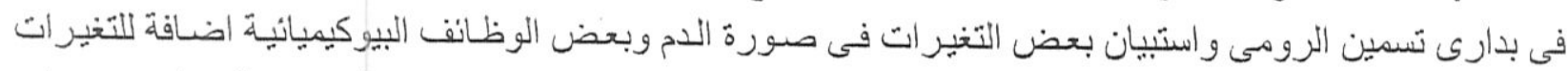

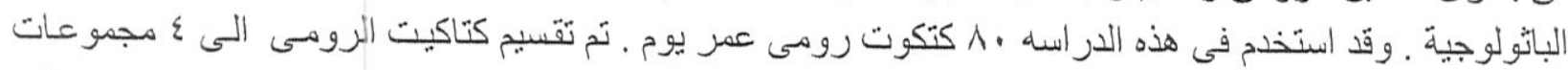

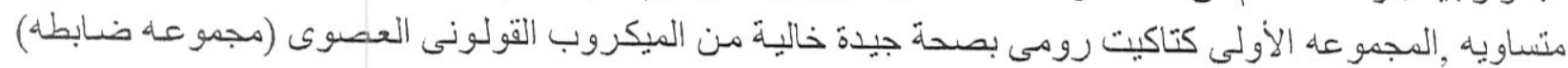

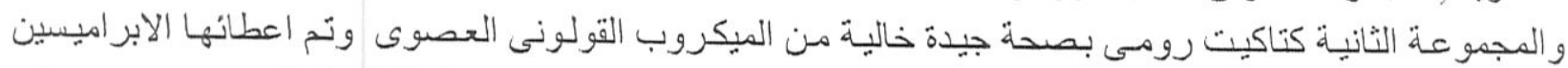

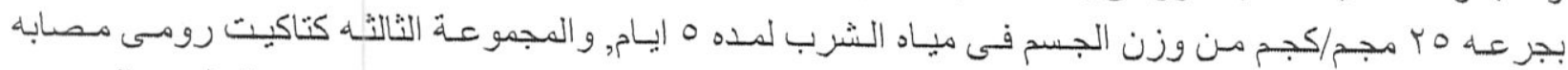

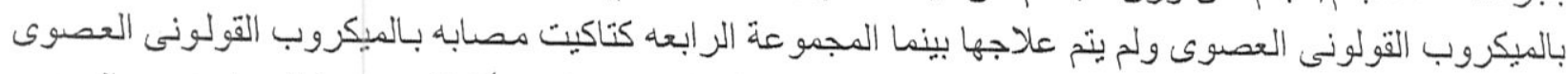

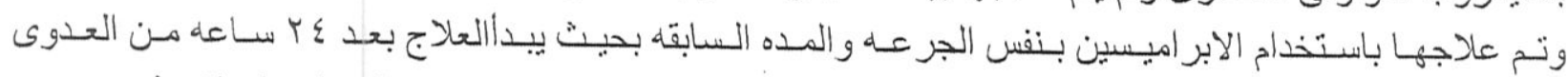

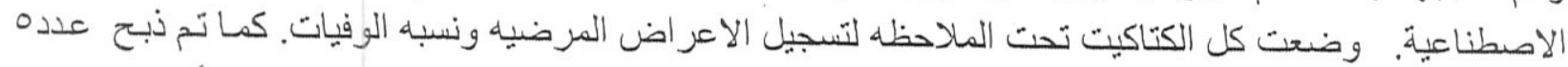

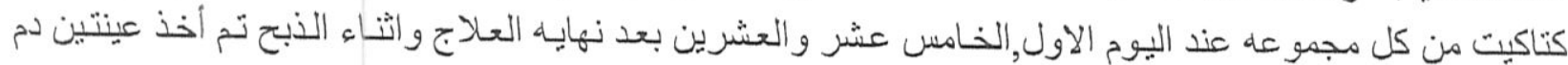

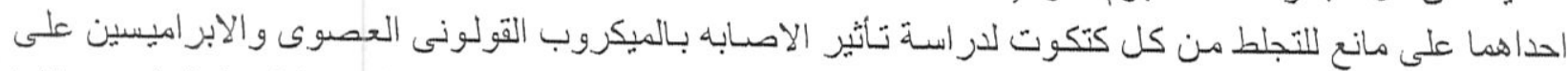
صورة الدم وبكض الوظائف البيوكيميائبة.وبعد الذبح يتم اخذ عينات من عضلات الفذذ, الكبد ,الكلى,الجلد لتعبيين بقايا

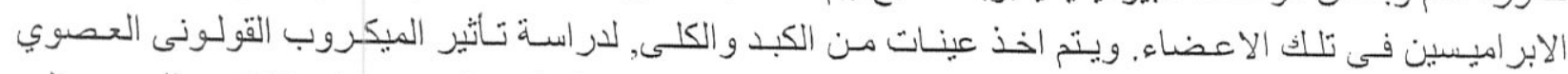

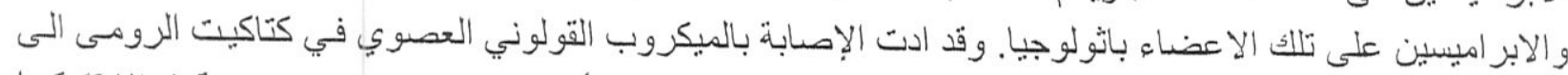

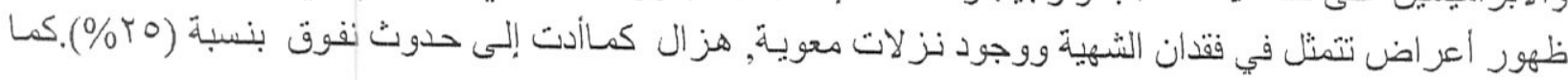


حدث نقص معنوى في عدد كريات الدم الحمر اءوتركيز الهيموجلوبين- وحجم خلايا الدم المرصوصـة_البروتين

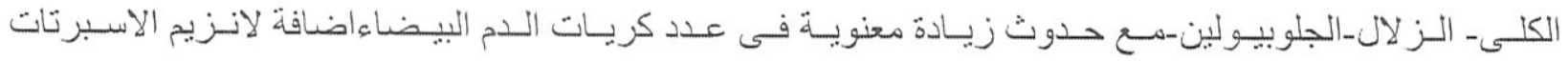

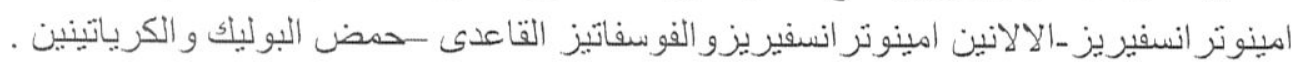

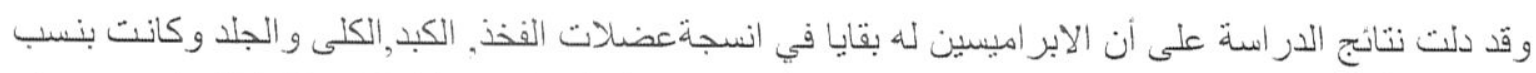

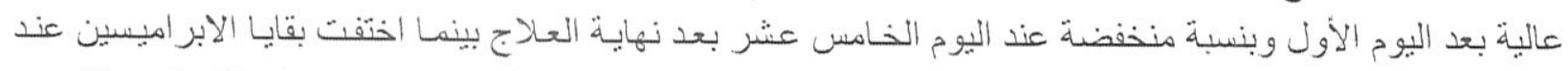

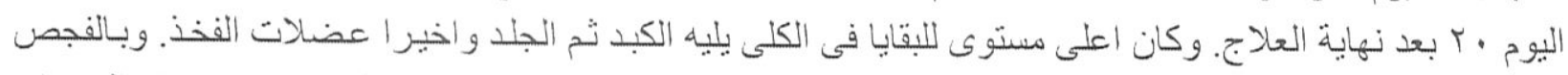

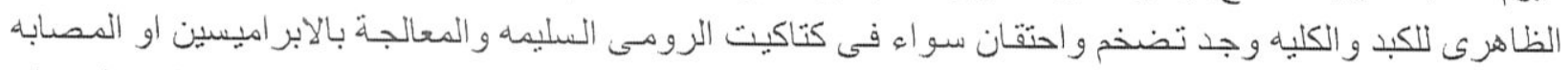

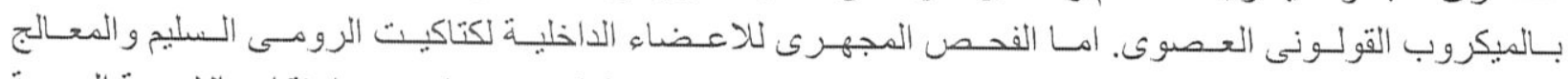

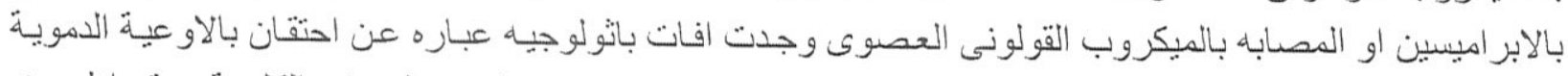

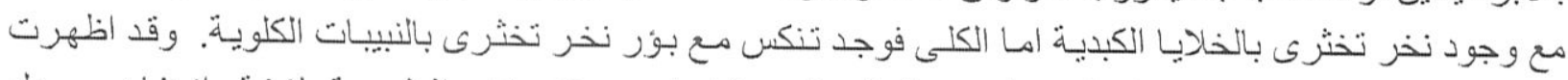

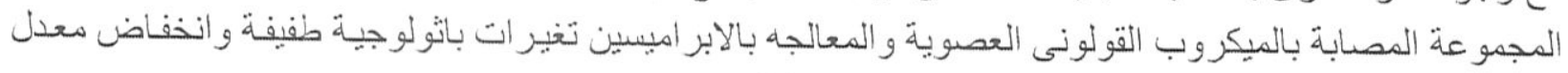
النفوق الى ٪\% و عودة وظائف الكبد و الكلى الى المستوى الطبيعى.

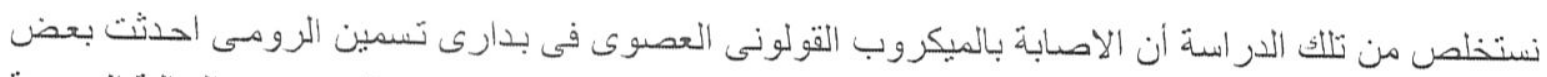

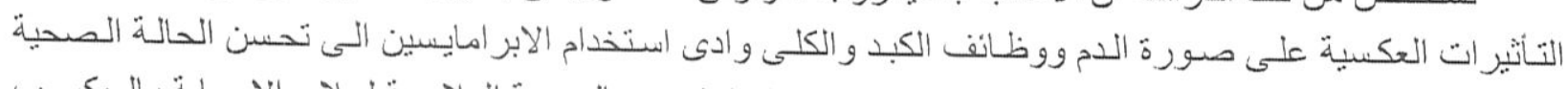

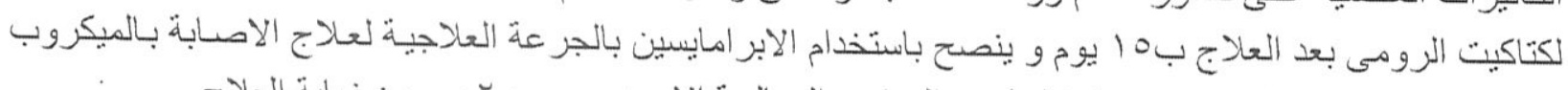

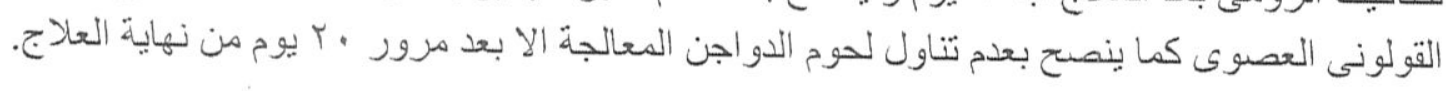

